Canadian Journal of Soil Science Revue canadienne de la science du sol

\title{
Effect of humic and fulvic substances and Moringa leaf extract on Sudan grass plants grown under saline conditions
}

\begin{tabular}{|r|l|}
\hline Journal: & Canadian Journal of Soil Science \\
\hline Manuscript ID & CJSS-2017-0050.R1 \\
\hline Manuscript Type: & Article \\
\hline Date Submitted by the Author: & 08-Jun-2017 \\
\hline Complete List of Authors: & $\begin{array}{l}\text { Merwad, Abdel-Rahaman; Faculty of Agriculture,Zagazig University, Egypt, } \\
\text { Soil Science }\end{array}$ \\
\hline Keywords: & Saline soil, Moringa leaf extract, humic and fluvic acids \\
\hline \multicolumn{2}{|c}{} \\
\hline
\end{tabular}

SCHOLARONE $^{\text {TH }}$

Manuscripts 
Effect of humic and fulvic substances and Moringa leaf extract on Sudan grass plants grown under saline conditions

Abdel-Rahman M. A. Merwad

Zagazig University

Faculty of Agriculture

Soil Science Department

44511 Zagazig

Egypt

Tel: + $0552554492 /$ +2 01212144240/ +2 01019203521

Fax: +20552347567

Corresponding author; e-mail: abdo.soil@yahoo.com

No. of pages : 30

No. of Tables : 5

No. of Fig.: 3

A short running title: Mitigation of salinity stress in Sudan grass by humic substances and Moringa extract

Key words: Saline soil, Moringa leaf extract, humic and fluvic acids 


\title{
Effect of humic and fulvic substances and Moringa leaf extract on Sudan grass plants grown under saline conditions
}

\author{
Abdel-Rahman M. A. Merwad \\ Soils Science Dept., Fac. Agric., Zagazig Univ., Egypt
}

Abstract

Salinity is the major stress factor, which limits crop cultivation, especially in developing countries. A randomized complete block, factorial (3-factor) experiment was conducted on Sudan grass grown on non-saline and saline soils to assess humic substances with or without foliar spraying Moringa leaf extract (MLE). Factors were :(A) Soil; 3 different levels of salinity i.e. $\mathrm{S}_{1}$ : non-saline $\left(\mathrm{EC}=3.01 \mathrm{dSm}^{-1}\right), \mathrm{S}_{2}$ : medium saline $\left(6.12 \mathrm{dSm}^{-1}\right)$ and $\mathrm{S}_{3}$ : highly saline $\left(12.33 \mathrm{dSm}^{-1}\right) ;(\mathrm{B})$ humic substances i.e. $\mathrm{B}_{0}$ : no addition, $\mathrm{B}_{1}$ : humic acid $(\mathrm{HA})$ as $\mathrm{K}$-humate, $\mathrm{B}_{2}$ : fluvic acid as K-fulvate and $B_{3}$ : HA and FA ; (C) foliar spray with MLE i.e. $\mathrm{C}_{0}$ : non-treated and $\mathrm{C}_{1}$ : foliar spray. Results indicated that total chlorophyll, nutrient uptake, available $\mathrm{N}, \mathrm{P}$ and $\mathrm{K}$ significantly decreased within each humic substances application and MLE with increasing salinity concentration. The highest values of fresh, dry weight, total chlorophyll and NPK- uptake under different salinity levels were observed with application of substances and MLE. Spraying of MLE increased cumulative yield and nutrient uptake by Sudan grass compared to the untreated ones. The treatment of HA and FA with or without spraying MLE gave the highest values of available NPK under the salinity levels.

Key words: Saline soil, Moringa leaf extract, humic and fluvic acids 
Introduction

Sudan grass is one of the important short-term forage crops of summer season. The Sudan grass and grain sorghum plants are chemically and morphologically similar, and with their hybrids are considered to be one of the emergency forage crops (Kidambi et al., 1993, Khair 1999)

Salinity refers to the total concentration of all soluble salts in the soil i.e., $\mathrm{Cl}^{-}, \mathrm{SO}_{4}{ }^{-2}$ or $\mathrm{CO}_{3}{ }^{-}$of $\mathrm{Na}^{+}, \mathrm{Ca}^{+2}$ and $\mathrm{Ma}^{+2}$ with the most common salt being $\mathrm{NaCl}$ (Jayasekera and Hall 2007). Salts inhibit plant growth by increasing the osmotic stress, nutritional imbalance, and specific ion toxicity. The extent of damage depends on the severity of stress, growth conditions and plant sensitivity to salinity (Cornillon and Palliox 1997). Increasing salinity stress was associated with significant decreases in P-uptake in straw and grain of barley plants (Ahmad 2007). Phosphorus (P) concentration in shoot of wheat was significantly decreased as soil salinity stress increased in both sandy and silty loam soils (Elgharably 2008). Salt stress induced a significant reduction in phosphorus of root. A non- significant effect of salinity stress was obtained on $\mathrm{P}$ concentration in leaf and grain rice (Naheed et al. 2008). Salinity increased the accumulation of $\mathrm{Na}^{+}$and decreased the $\mathrm{K}^{+}$content in shoots and roots. The $\mathrm{Na}^{+}$ content of germinating seeds gradually increased, while $\mathrm{K}^{+}$content diminished (Akbarimoghaddam 2011 and Abd EL-Azim and Ahmed 2009). Nutrient uptake (N, P, K) by wheat plants decreased with increasing soil salinity levels (Elrys 2012). Humic substances may play a positive role in regulating the plant root metabolism by inducing or repressing the mechanism of protein synthesis, enzyme activation or inhibition resulting in morphofunctional changes in plant root tissues (Cacco et al. 2000 and Türkmen et al. 2004). Humic substances might show anti-stress effects under abiotic stress conditions such as, unfavorable temperature, $\mathrm{pH}$, salinity etc. 
Humic materials could improve growth of plant under soil condition with enhancing nutrients uptake and reducing toxic elements uptake (Kulikova et al. 2005). Sharif et al. 2002 found that the humus material has indirect effects on plant growth because it improves soil properties i.e., water holding capacity, permeability, aggregation, hormonal activity, aeration, organic matter mineralization, and solubilization and nutrients availability (Nardi et al. 2002). Merwad and Abdel-Fattah (2015) found that the application of chicken manure combined with HA increased growth parameters, total chlorophyll, carotenoids, yield and nutrient uptake of sorghum compared with untreated.

Foidle et al. (2001) reported that MLE have plant growth enhancing capabilities as it is rich in zeatin, carotenoids, phenols, potassium and calcium. Fuglie 2000 reported that spraying MLE increased growth and yield of tomato, peanut, corn and wheat 20 to 35. The solvent of MLE are potential source of natural antioxidants (Siddhuraju and Becker, 2003 ; Arabshahi et al., 2007 and Athar et al., 2008). Foliar spray of MLE exhibit highest antioxidant status as compared to other growth enhancers up to moderate salinity $\left(8 \mathrm{dSm}^{-1}\right)$ except ascorbic acid which continued to be increased up to highest salinity level $\left(12 \mathrm{dSm}^{-1}\right)$. Moreover, the increase in ascorbic acid under MLE application in salinity stress was largest than all other enzymatic and nonenzymatic antioxidants. The objective of the current study was to test the effect of humic substances (humic and fulvic acids) with spraying Moringa leaf extract on yield, and nutrient uptake of Sudan grass grown under saline conditions.

Materials and methods

Experiment set up and design

A pot experiment was conducted under the green house conditions at the farm of the Faculty of Agriculture Zagazig University, Egypt. The design was a randomized 
complete block, factorial (3-factor experiment) .The plant was Sudan grass (Sorghum vulgare var. Sudanense) grown on loamy soils (Calciorthid) collected from ElNoubaria, near Alexandria, Egypt. The 3 factors of the experiment were :(A) Soil; 3 different loamy soils of different natural (inherent) salinity (see Table 1 for properties of the soils $)$ i.e. $\mathrm{S}_{1}$ : non-saline $\left(\mathrm{EC}=3.01 \mathrm{dSm}^{-1}\right), \mathrm{S}_{2}$ : medium saline $(6.12$ $\mathrm{dSm}^{-1}$ ) and $\mathrm{S}_{3}$ (highly saline $12.33 \mathrm{dSm}^{-1}$ ) ; (B) humic substances treatment i.e. $\mathrm{B}_{0}$ :no addition, $\mathrm{B}_{1}$ : adding humic acid (HA) as potassium humate, $\mathrm{B}_{2}$ : adding fulvic acid (FA) as potassium fulvate and $\mathrm{B}_{3}$ : adding humic and fluvic acids. The soil material for the experiment was collected from the surface $0-30-\mathrm{cm}$ of the soil. (C) Foliar spray with MLE i.e. $\mathrm{C}_{0}$ non-treated and $\mathrm{C}_{1}$ foliar spray with the MLE. The soil was sieved through 5-mm and thoroughly mixed before filling the pots. Closed bottom PVC pots (10-kg capacity each) of 35-cm diameter and 30-cm height were used. Sudan grass seeds were obtained from the Crops Research Institute, Agriculture Research Centre, Giza, Egypt. Seeds were sown on the $1^{\text {st }}$ of April, 2015. Twenty seeds were sown in each pot. Twelve days after sowing, plants were thinned to 10 per pot. Total of 3 cuts were taken. Physical and chemical properties of the soils were determined according to Piper 1951, Black et al. 1965, Jackson 1973.

Fertilization and humic substances application

Before planting, the treatments of humic substances i.e. humic acid (HA) as potassium humate and fulvic acid (FA) as potassium fulvate were thoroughly mixed with the soil at the rate of $0.002 \mathrm{~g} \mathrm{~kg}^{-1}$ (equivalent to about $5 \mathrm{~kg} \mathrm{ha}^{-1}$ ) mixed with fine sand ( $3 \mathrm{~g}$ per pot) as a filling material. Nitrogen was added as ammonium sulphate at the rate of $150 \mathrm{mg} \mathrm{N} \mathrm{kg}^{-1}$ soil at three equal splits. The first was before the first irrigation while the second and third splits were added after the first and second cuts, 
respectively from the first splits. The recommended doses of $\mathrm{P}$ and $\mathrm{K}$ were added; for all experimental treatments as ordinary super phosphate $\left(65 \mathrm{~g} \mathrm{P} \mathrm{kg}^{-1}\right)$ at the rate of 15 $\mathrm{mg} \mathrm{P} \mathrm{kg}{ }^{-1}$ soil before sowing. $\mathrm{K}$ was added as potassium sulphate $\left(410 \mathrm{~g} \mathrm{~K} \mathrm{~kg}^{-1}\right)$ at the rate of $40 \mathrm{mg} \mathrm{K} \mathrm{kg}^{-1}$ soil before sowing.

Preparation of Moringa leaf extract

An amount of $20 \mathrm{~g}$ of young Moringa oleifera leaves was mixed with $675 \mathrm{ml}$ of $80 \%$ ethanol as suggested by Makkar and Becker (1996). The suspension was stirred using a homogenizer to help maximize the amount of the extract. The solution was filtered using No.2 Whatman filter paper. MLE was used within $5 \mathrm{~h}$ from cutting and extracting (if not ready to be used, the extract or the solution prepared was stored at $0^{\circ} \mathrm{C}$ and only taken out when needed for use). The chemical composition of ethanolic MLE was investigated using Fuglie (2000) and Moyo et al. (2011) are represented in Table (2). Extracts used for spray were dilutes of $30 \mathrm{~mL}$ extract $\mathrm{L}^{-1}$ of water (3\%). Foliar application was done in 9 occasions: 20, 30 and 40 days after germination and before $1^{\text {st }}$ cut, then similar intervals after $1^{\text {st }}$ cut, and also after $2^{\text {nd }}$ cut (cuts are 60 days apart). Control plants (non-treated with MLE) were sprayed with distilled water.

Plant harvesting and analysis

Three cuts were taken from the Sudan grass. Each cut was taken after 60 day of growth. Plant height, fresh weight, dry matter, nutrient concentration and total chlorophyll of Sudan grass were measured at each harvest. Total chlorophyll were determined spectrophotometrically (Metzner et al. 1965). Proline concentration was determined according to the method given by Bates et al. (1973). Plant samples taken 
at three different cuts, and dried at $70^{\circ} \mathrm{C}$ until constant weight, digested and determining nutrient concentration (Chapman and Pratt 1961).

Soil analysis

Available P was determined using Watanabe and Olsen (1965) method, $5 \mathrm{~g}$ of soil sample being shaken with $50 \mathrm{ml} 0.5 \mathrm{M} \mathrm{NaHCO}_{3}$ solution ( $\mathrm{pH} 8.5$ ) with one gram activated charcoal for 0.5 hour and filtered. Available $\mathrm{N}$ was determined using method described by (Jackson 1973), $5 \mathrm{~g}$ of each soil sample was shaken with $50 \mathrm{ml} 2$ $\mathrm{N} \mathrm{KCl}$ solution and filtered. Available $\mathrm{N}$ was assayed in the soil extract using kjeldahl apparatus. Available potassium being extracted by $1 \mathrm{~N} \mathrm{NH}_{4} \mathrm{OAC}$ solution and assayed by flame photometer (Jackson 1973).

\section{Statistical analyses}

Data of the current study were subjected to analysis of variance for a split-split bloks design, after testing for the homogeneity of error variances. Statistically significant differences between means were compared at $P \leq 0.05$ using Duncan's Multiple Range Test. The statistical analysis was carried out using COSTAT computer software (CoHort Software version 6.303, Berkeley, CA, USA).

\section{Results and discussion}

Fresh and dry weight

The application of various humic substances with MLE gave an increase in the total yield of plants in the three cuts grown under different salinity level compared to untreated soil (Table 2). This is explained on the fact that the additionof humic materials improve physical and chemical characteristics of saline soil. This finding stands in agreement with those of Nardi et al. (2002), Cimrin and Yilmaz 2005, Merwad and Abdel-Fattah 2015 and Thanaa et al., 2017. 
Concerning the effect of saline soil salinity, data reveal that, the cumulative yield of Sudan grass was decreased by increasing the soil salinity level. This trend was found true under different humic substances with MLE, at all three cuts. As mentioned above the plants at three cuts were damaged with the control treatment due to extremely high salinity $\left(12.33 \mathrm{dSm}^{-1}\right)$. Salts inhibit growth of plant by increasing specific ion toxicity, osmotic stress and nutritional imbalance. The extent of damage depends on the severity of stress, growth conditions and plant sensitivity to salinity (Cornillon and Palliox 1997). Elgharably (2008) reported that increasing the salinity during the growing season significantly reduced the total dry matter accumulation, straw and grains yield of wheat.

Regarding the effect of humic substances, data indicate that the application of individual HA or combination with FA gave the higher values of cumulative yield of plants at three cuts under all salinity levels than single fulvic acid addition in the presence of MLE. Main effect of humic materials are as follows HA and FA > HA > FA $>$ None. The highest values of fresh and dry weight at three cuts under S1(3.01 $\left.\mathrm{dSm}^{-1}\right), \mathrm{S} 2\left(6.12 \mathrm{dSm}^{-1}\right)$ and $\mathrm{S} 3\left(12.33 \mathrm{dSm}^{-1}\right)$ levels were observed with addition of HA and FA (554, 510 and $439 \mathrm{~g} \mathrm{pot}^{-1}$, respectively for fresh weight and 92.41, 85.04 and $73.15 \mathrm{~g} \mathrm{pot}^{-1}$, respectively for dry weight ) under spraying of MLE, while the lowest one (512, 466 and $331 \mathrm{~g} \mathrm{pot}^{-1}$, respectively for fresh weight and 85.36,77.60 and $55.16 \mathrm{~g} \mathrm{pot}^{-1}$, respectively for dry weight) was recorded under the control in the absence of MLE. From statistical analysis, results showed that spraying MLE gave significant increase in fresh and dry weight of plants compared to control plants.

Spraying of MLE increased cumulative fresh weight of Sudan grass plants compared to the untreated ones (Table 2). These increases represent 3.9, 2.3, 3.3 and $2.8 \%$ under $\mathrm{S} 1\left(3.01 \mathrm{dSm}^{-1}\right)$ level for the treatments of untreated, HA, FA, HA + FA, 
respectively; $3,2.9,1.5$ and $2.4 \%$, respectively under $\mathrm{S} 2\left(6.12 \mathrm{dSm}^{-1}\right)$ level and $2.4,3.6,3.2$ and $3.3 \%$, respectively under $\mathrm{S} 3\left(12.33 \mathrm{dSm}^{-1}\right)$ level. MLE is a highly nutritive multipurpose plant grown for vegetables, livestock fodder, green manure, biogas, medicine, bio pesticide, and seed production (Fuglie, 2000). Foliar spray with MLE increased plant growth and yield by 20-35\% (Foidle et al. 2001; Makkar and Becker 1996, Nouman et al. 2011, Basra et al. 2005 and Merwad 2015a, b). MLE is rich with ascorbic acid, mineral nutrients i.e, Fe, $\mathrm{K}, \mathrm{Ca}$ and amino acids and had an effect on increasing the plant growth (Makkar and Becker 1996; Basra et al. 2009; Merwad and Abdel-Fattah, 2016 and Thanaa et al., 2017).

Plant height, total chlorophyll and proline

Addition of different humic substances as well as foliar spray with MLE caused positive significant effects on plant height, total chlorophyll and proline of Sudan grass grown under salinity level (Table 3 ). The highest values of plant height, total chlorophyll and proline under S1 (3.01 dSm $\left.\mathrm{dSm}^{-1}\right), \mathrm{S} 2\left(6.12 \mathrm{dSm}^{-1}\right)$ and $\mathrm{S} 3\left(12.33 \mathrm{dSm}^{-1}\right)$ levels (140, 118 and $73.5 \mathrm{~cm}$, respectively for plant height; $1.7,1.46$ and $1.27 \mathrm{mg} / \mathrm{g}$ fwt, respectively for total chlorophyll and $16.3,17.4$ and $22.4 \mathrm{mg} \mathrm{g}^{-1} \mathrm{dwt}$, respectively for proline) were obtained by HA and FA under sprayed MLE, while the lowest one was obtained in plants not receiving humus materials as well as MLE. Addition of HA significantly increased plant pigments, i.e. chlorophyll a, total chlorophyll and carotenoids concentrations under calcareous soils conditions (Hanafy et al. 2010; Merwad 2015a and Shuixiu and Ruizhen 2001).

Regarding the effect of soil salinity, data reveal that, the plant height and total chlorophyll of Sudan grass was decreased with increasing the soil salinity levels. On the other hand, proline was increased with increasing the soil salinity level. This trend was found true under different humus materials with MLE, at all three cuts. As 
mentioned above the plants at three cut died off with the control soil due to extremely high salinity $\left(12.33 \mathrm{dSm}^{-1}\right)$. Salinity treatments have a depressing effect on various growth parameters was increased prominently with increasing salinity level (Mazher et al. 2008 and Parida and Das 2005). Chlorophyll reduction probably is due to the inhibitory effect of accumulation of ions on biosynthesis of different ingredients of chlorophyll (Tejera et al. 2006 and Poustini et al. 2007).

Spraying MLE increased the plant height by averages 11.5, 17.5, 14.4 and $15.3 \%$ under the treatments of untreated, HA, FA, HA+FA, respectively under various level of soil salinity; Moreover it increased proline by averages of $10.3,10,8.5$ and $9 \%$, respectively. MLE is rich with source of vitamin $\mathrm{C}, \beta$-carotene, protein, $\mathrm{Ca}, \mathrm{Fe}, \mathrm{K}$, natural antioxidants such as ascorbic acid, flavonoid, phenolics and carotenoids (Dillard and German 2000, Siddhuraju and Becker 2003, Merwad 2015b Merwad and Abdel-Fattah, 2016; Thanaa et al., 2017 ; Raje and Mestry, 2017; Abusuwar and Abohassan 2017).

Nutrient uptake

Addition of various humic substances as well as foliar of MLE spray caused a positive significant effect on individual and cumulative N,P and K- uptake (mg pot $^{-1}$ ) of the successive cuttings of Sudan grass grown under various levels of soil salinity (Table 4). The highest values of N, P and K-uptake were obtained with HA and FA combined with MLE spray under S1 $\left(3.01 \mathrm{dSm}^{-1}\right), \mathrm{S} 2\left(6.12 \mathrm{dSm}^{-1}\right)$ and S3 (12.33 $\mathrm{dSm}^{-1}$ ) levels. However untreated plants showed the lowest $\mathrm{N}, \mathrm{P}$ and K- uptake. Treatments could be arranged in the following order regarding the main effects $\mathrm{HA}+$ FA $>$ HA $>$ FA $>$ untreated under various level of soil salinity with foliar spray of MLE (Merwad 2015b). Addition of HA increased plant growth and the nutrients accumulation of wheat (Asik et al. 2009 and Arancon et al. 2006). The addition of 
humus substances showed anti-stress effects under a biotic stress conditions such as, unfavorable temperature, $\mathrm{pH}$, salinity etc.(Kulikova et al. 2005). Potassium humate $(1.0 \%)$ treated crop plants showed significantly increased on nutrients accumulation of wheat (Patil et al. 2011).

In general, results of the cumulative $\mathrm{N}, \mathrm{P}$ and K-uptake as affected by application of various humic substances with moringa spraying gave an increase in the three cuts of plants grown under salinity stress $\left(3.01,6.12\right.$ and $12.33 \mathrm{dSm}^{-1}$ ) compared to the control; this result could be due to the high total dry weight as a result of the effects of treated humic substances with MLE (Merwad 2015b).

Regarding the effect of soil salinity, data in Table (4) show that, the N, P and Kuptake by Sudan grass plants was decreased with increasing the soil salinity level. This trend was found true under different humic substances with MLE, at all three cuts. As mentioned above the plants at three cut died off in the control treatment due to extremely high salinity $\left(12.33 \mathrm{dSm}^{-1}\right)$. Ahmad (2007) found that increasing salinity stress was associated with significant decreases in NPK accumulation by straw and grains of barley plants. Saqib et al. (2004) stated the concentration of NPK in wheat plants decreased with increasing the salinity stress. Hadad (2006) reported that the NPK concentration and its uptake by barely plants decreased with increasing EC.

Spraying of MLE increased cumulative N-uptake by Sudan grass plants compared to the untreated ones (Table 4). These increases represent 11, 8.7, 9.4 and 8.3\% under S1(3.01 dSm$\left.~_{-1}\right)$ level for the treatments of untreated, HA, FA, HA and FA, respectively; $10.4,8.9,13.8$ and $3.2 \%$, respectively under $\mathrm{S} 2\left(6.12 \mathrm{dSm}^{-1}\right)$ level and $5.1,7.7,8.8$ and $12 \%$, respectively under $\mathrm{S} 3\left(12.33 \mathrm{dSm}^{-1}\right)$ level. Treatments under spraying MLE gave higher value of P-uptake than those under untreated. These increases represent $23,12.4,17.6$ and $10 \%$ under $\mathrm{S} 1\left(3.01 \mathrm{dSm}^{-1}\right)$ level for the 
treatments of untreated, HA, FA, HA and FA, respectively; 17.8, 11, 12.6 and 11\%, respectively under $\mathrm{S} 2\left(6.12 \mathrm{dSm}^{-1}\right)$ level and $21,21,16$ and $14.8 \%$, respectively under S3 (12.33 $\left.\mathrm{dSm}^{-1}\right)$ level. The same trend was found with the potassium uptake (Merwad 2015b; Raje and Mestry, 2017 and Abusuwar and Abohassan, 2017).

Salinity also produces ionic stress leading to ionic imbalances and impairment of root membrane selectivity. Athar et al. 2008 showed that addition of ascorbic acid increased leaves $\mathrm{K}^{+}$accumulation under salinity. Addition of MLE and $\mathrm{H}_{2} \mathrm{O}_{2}$ decreased concentration of $\mathrm{Na}^{+}$and $\mathrm{Cl}^{-}$along with increased $\mathrm{K}^{+}$in leaves against control (Makkar et al., 2007).

Soil $\mathrm{pH}$ and available nutrients

Effect of soil salinity and humic substances with MLE on soil $\mathrm{pH}$, available $\mathrm{N}, \mathrm{P}$ and $\mathrm{K}$ concentration in the soils was illustrated in (Figs 1 and 2). Respecting the soil salinity effect, results reveal that, the available N, P and K in the soils were decreased with increasing the soil salinity level. This trend was found true under different humic substances with spraying MLE. On the other hand, results show that, soil $\mathrm{pH}$ was decreased with the application of humus materials with or without MLE under soil salinity level. Obtained results are similar to those reported by Elgharably, 2008 and Vuelvas-Solozano et al., 2009 who observed significant negative effects of soil salinity on availability of $\mathrm{N}$ and $\mathrm{P}$ in wheat in loam soil. He attributed his results to the inhibitory effects of salinity stress on soil microbial activity, and in turn, on organic $\mathrm{N}$ mineralization.

The available $\mathrm{N}, \mathrm{P}$ and $\mathrm{K}$ concentration in the soils were increased with the addition of various humic substances under the salinity levels. The treatment of HA and FA with or without spraying MLE gave the highest values of available N, P and K under the salinity levels, while the lowest were found with untreated soil. The 
promotive effect of various humus materials on soil $\mathrm{pH}$, available $\mathrm{N}, \mathrm{P}$ and $\mathrm{K}$ concentrations in the soil may follow the order of: HA and FA $>$ HA $>$ FA $>$ untreated soils (Merwad and Abdel-Fattah 2015; Raje and Mestry, 2017 and Abusuwar and Abohassan, 2017).

Application various humic substances increased the mean values of available $\mathrm{N}, \mathrm{P}$ and $\mathrm{K}$ in soil under salinity levels compared to the untreated ones (Figs 1 and 2).These increases represent $18.5,48$ and $75 \%$ for available nitrogen; 25,64 and $96 \%$ for available phosphorus and 22, 36.7 and $76.8 \%$ for available potassium under application HA, FA, HA and FA treatments, respectively. Application of HA combined with $\mathrm{P}$ fertilizer significantly increased the content of water-soluble phosphate, strongly retarded the formation of occluded phosphate, and increased $\mathrm{P}$ accumulation by $25 \%$ (Wang et al. 1995). The effect of HA and FA on the dissolution of aluminum phosphate and iron phosphate, and assessed their availability to plants.. Humic acid was more effective than fulvic acid in dissolving the metal phosphates. Addition of HA released the fixed K (Mesut et al. 2010). Soil addition of HA at $50 \mathrm{mg}$ $\mathrm{kg}^{-1}$ mixed with $\mathrm{P}$ fertilizer at a recommended dose significantly increase availability of soil organic matter, Phosphorus, Potassium and Boron by16, 60, 4 and 34\%, respectively compared to $100 \%$ of $P$ fertilizer alone (Sarwar et al. 2012)

Relationship between $\mathrm{K}$ and $\mathrm{Na}$ in Sudan grass as affected by treatments.

Under saline conditions, high levels of external $\mathrm{Na}^{+}$not only interfere with $\mathrm{K}^{+}$ acquisition by the roots, but also may disrupt the integrity of root membranes and alter their selectivity. The selectivity of the root system for $\mathrm{K}^{+}$over $\mathrm{Na}^{+}$must be sufficient to meet the levels of $\mathrm{K}^{+}$required for metabolic processes, the regulation of ion transport, and for osmotic adjustment (Hu and Schmidhalter 2005). 
The relation between $\mathrm{K}$ and $\mathrm{Na}$ concentration $\left(\mathrm{g} \mathrm{kg}^{-1}\right)$ in Sudan grass at different cuts was shown in (Figure 3). The potassium concentration in Sudan grass plants at three cuts was reported to be decreased with increasing soil salinity stress. However, the Na concentration tended to increase with increasing the soil salinity. Overall, there was a positive relationship between $\mathrm{K}$ and $\mathrm{Na}$ concentration in Sudan grass at three cuts. The correlation coefficient (r) values between $\mathrm{K}$ and $\mathrm{Na}$ concentration in Sudan grass were $0.96,0.93$ and 0.88 at the $1^{\text {st }}, 2^{\text {sd }}$ and $3^{\text {rd }}$ cuts. This adverse relationship between $\mathrm{K}$ and $\mathrm{Na}$ concentration in plant tissues was found true at all cuts under all treatments. Hossain et al. (2006) reported that the various soil salinity of $\mathrm{NaCl}$ decreased mineral ion accumulation in wheat plants; the acculturation of $\mathrm{Na}$ increased while that of $\mathrm{K}$ decreased in the salt treated plants.

\section{Conclusion}

Salinity is a major limiting factor for plant growth and productivity. The decrease was proportional to the increase in salinity concentration. Applying humic acid as Khumate or fluvic acid as K-fulvate singly or combined to the soil alleviated the negative effect caused by salinity to plant growth (Sudan grass, three cuts). The effect was strengthened with spraying the plants with MLE. Increases occurred in plant growth parameters of yield, chlorophyll, NPK-uptake. Treatments also showed a decrease in Na content in plant. Spraying of MLE combined with addition of humic substances and materials can be a practical preposition to help plants endure salinity when grown on saline soils increasing their yields and nutrient uptake. The available $\mathrm{N}, \mathrm{P}$ and $\mathrm{K}$ in the soils were decreased with increasing the soil salinity level. Soil $\mathrm{pH}$ was decreased with addition of humic materials with or without MLE under soil salinity level. Generally, the best results of all of the growth characteristics, nutrients uptake and available NPK in soil were obtained from HA and FA application with 
MLE within every individual salinity concentration. More research may be needed to clarify the mechanisms of alleviation done by fulvic and humic acids and their salts.

References

Abd EL-Azim WM, Ahmed STH. 2009. Effect of salinity and cutting date on growth and chemical constituents of Achillea fragratissima Forssk, under Ras Sudr conditions. Res J Agri Biol Sci. 5:1121-1129.

Abusuwar AO, Abohassan RA. 2017. Effect of Moringa oliferaLeaf Extract on Growth and Productivity of Three Cereal Forages. Journal of Agricultural Science; 9 (7): 236-243.

Ahmad SAA. 2007. Response of Plant to Phosphorus Fertilization under Different Levels of Salinity Stress. M Sc Thesis Fac Agric Benha Univ.

Akbarimoghaddam H, Galavi M, Ghanbari A, Panjehkeh N. 2011. Salinity effects on seed germination and seedling growth of bread wheat cultivars. Trakia J Sci. 9: 43-50.

Arabshahi DS, Vishalakshi DD, Asna U. 2007. Evaluation of antioxidant activity of some plant extracts and their heat, $\mathrm{pH}$ and storage stability. Food Chem. 100: 1100- 1105 .

Arancon NQ, Edwards CA, Lee S, Byrne R. 2006. Effects of humic acids from vermicomposts on plant growth. Soil Bio. 42: 565-569.

Asik BB, Turan MA, Celik H, Katkat AV. 2009. Effect of humic substances to dry weight and mineral nutrients uptake of wheat on saline soil conditions. Asian $\mathbf{J}$ crops sci. 1: 87-95.

Athar H, Khan A, Ashraf M. 2008. Exogenously applied ascorbic acid alleviates salt induced oxidative stress in wheat. Environ Exp Bot. 63:224-231. 
Basra SMA, Afzal I, Anwar S, Shafique M, Haq A, Majeed K. 2005. Effect of different seed invigoration techniques on wheat (Triticum aestivum L.) seeds sown under saline and non-saline conditions. J Seed Technol. 28: 36-45.

Basra SMA, Zahar M, Rehman H, Yassmin A, Munir H. 2009. Evaluating the response of sorghum and Moringa leaf water extracts on seeding growth in hybrid maize. In : Proceedings of the International Conference on Sustainable Food Grain Production: Challenges and Opportunities. University of Agriculture, Faisalabad, Pakistan, p. 22.

Bates LS, Waldern RP, Teare ID. 1973. Rapid determination of free proline for water stress studies. Plant Soil. 39: 205-208. http://dx.doi.org/10.1007/BF00018060

Black CA, Evans DD, Ensminger LE, White JL, Clarck, FE.1965. Methods of Soil Analysis. Amer Soc Agron, Madison, Wisconsin, USA.

Cacco G, Attina E, Gelsomino A, Sidari M. 2000. Effect of nitrate and humic substances of different molecular size on kinetic parameters of nitrate uptake in wheat seedlings. J Plant Nutr Soil Sci. 163: 313-320.

Cimrin KM, Yilmaz I. 2005. Humic acid applications to lettuce do not improve yield but do improve phosphorus availability. Acta Agric Scan. Section B- Soil Plant Sci. 55: 58-63.

Cornillon P, Palliox A. 1997. Influence of sodium chloride on the growth and mineral nutrition of pepper cultivars. J Plant Nutr. 20: 1085-1094.

Chapman DH, Pratt PF. 1961. "Methods of analysis for soil, plant and waters". California. Univ.; Division of Agric. Sci.

Dillard CJ, German JB. 2000. Phytochemicals: Nutraceuticals and human health. J Sci Food Agric. 80:1744-1756. 
Elgharably AG. 2008. Nutrient Availability and Wheat Growth as Affected by Plant Residues and Inorganic Fertilizers in Saline Soils. Ph.D. Thesis. Soil and land systems, Earth Environ. Sci, Univ Adelaide, Aust.

Elrys ASA. 2012. Effect of Nitrogen Fertilization from Different Sources on Soil and Plant under Saline Conditions. MSc Soils Dept Fac Agric Zagazig Univ.

Foidle N, Makkar HPS, Becker K. 2001.The potential of Moringa oleifera for agricultural and industrial uses. p. 45-76. In L. Fuglie (ed.) The miracle tree: The multipurpose attributes of Moringa. CTA publications. Wageningen, the Netherlands.

Fuglie LJ. 2000. The Miracle Tree : Moringa oleifera: Natural Nutrition for the Tropics. The multiple Attributes of Moringa, p. 172.

Hadad HM. 2006. Effect of saline irrigation water on some soil properties and growth of certain wheat and barley cultivars grown on a sandy calcareous soil. MSc Thesis Fac Agric Assiut Univ

Hanafy AAH, Nesiem MR, Hewedy AM, Sallam HE. 2010. Effect of some simulative compounds on growth, yield and chemical composition of snap bean plants grown under calcareous soil conditions. J Amer Sci. 6: 10-16.

Hossain AA, Halim MA, Hossain F, Niger M. 2006. Effects of $\mathrm{NaCl}$ salinity on some physiological characteristics of wheat (Triticum asetivium L.). Bangladesh J Bot. 35: 9-15.

Hu Y, Schmidhalter U. 2005. Drought and salinity: A comparison of their effects on mineral nutrition of plants. J Plant Nutr Soil Sci. 168: 541-549.

Jackson ML. 1973. Soil Chemical Analysis. Prentice Hall, Ic., Englewood Califfs, New Jersy. 
Jayasekera S, Hall S. 2007. Modification of the properties of salt affected soils using electrochemical treatments. Geotech Geol Eng. 25:1-10.

Kulikova NA, Stepanova EV, Koroleva OV. 2005. Mitigating activity of humic substances: Direct influence on biota. In: Use of humic substances to remediate polluted environments: From theory to practice (Ed.: I.U. Perminova). NATO Science Series IV. Earth and Environmental Series. Kluwer Academic Publishers, 285-309.

Kidambi SP, Matches AG, Karnezos TP, Keeling JW.1993. Mineral concentrations in forage sorghum grown under two harvest management systems. Agron J. 85: 826-833.

Khair MA. 1999. Principles production of forage crops. Training and Publishing Department, Agricultural Research Committee, Sudan.

Mackowiak CL, Grossl PR, Bugbee BG. 2001. Beneficial effects of humic acid on micronutrient availability to wheat. Soil Sci Soc Amr J. 65: 1744-1750.

Makkar HPS, Becker K. 1996. Nutritional value and ant nutritional components of whole and ethanol extracted of Moringa oleifera leaves. Anim Feed Sci Technol. 63:211-228.

Makkar HPS, Francis G, Becker K. 2007. Bioactivity of phytochemicals in some lesser-known plants and their effects and potential applications in livestock and aquaculture production systems. Animal 1: 1371-1391.

Mazher AAM, Zaghloul SM, El-Mesiry T. 2008. Nitrogen forms effects on the growth and chemical constituents of Taxodium disticum grown under salt conditions. Aust J Basic Appl Sci. 2: 527-534. 
Merwad AMA, Abdel-Fattah MK. 2015. Effect of some soil amendments and foliar spray of salicylic and ascorbic acids on sorghum under saline calcareous soil conditions. Internal J Soil Sci.10 (1): 28-36.

Merwad AMA. 2015a. Effect of Moringa oleifera extracts on the growth, yield and nutrient uptake of spinach (Spinacia Oleracea L.). Greener J Soil Science and Plant Nutrition. 2 (1): 16-22.

Merwad AMA. 2015b. Potential of Moringa Oleifaera for Agricultural Use. www. scholars-press. ComLambert Academic Publishing in USA, UK and Germany.

Merwad AMA, Abdel-Fattah MK. 2016. Improving productivity and nutrients uptake of wheat plants using Moringa oleifera leaf extract in sandy soil. Journal of Plant Nutrition, DOI: 10.1080/01904167.2016.1263318.

Metzner H, Rau H, Senger H. 1965. Unter suchungen zur synchronisier barkeit ein zeiner pigment. Mangol Mutanten von Chlorella plants. 65: 186-191.

Mesut K, Cimrin O, Türkmen MT, Burcu T. 2010. Phosphorus and humic acid application alleviate salinity stress of pepper seedling. African Journal of Biotechnology. 9(36): 5845-5851

Moyo B, Masika PJ, Hugo A, Muchenje V. 2011. Nutritional characterization of Moringa (Moringa oleifera Lam) leaves. Afr J Biotechnol. 10(60):12925 12933.

Naheed G, Shahbaz M, Akram NA. 2008. Interactive effect of rooting medium application of phosphorus and $\mathrm{NaCl}$ on plant biomass and mineral nutrients of rice (Oryza sativa L.). Pak J Bot. 40: 1601-1608.

Nardi S, Pizzeghello D, Muscolo A,Vianello A. 2002. Physiological effects of humic substances in plant growth. Soil Biol Biochem. 34: 1527-1536.

Nouman W, Siddiqui MT, Basra SMA. 2011. Moringa oleifera leaf extract: An innovative priming tool for rangeland grasses. Turk J. 35:1009-1261. 
Raje S, Mestry A. 2017. Beneficial effect of Moringa oleifera on Lead induced Oxidative stress. Int. J. Life Sciences, 5 (1): 63-72.

Parida AK, Das AB. 2005. Salt tolerance and salinity effects on plants: A review. Ecotoxicol Environ Safety. 60: 324-329.

Patil RB, More AD, Kalyankarm ASS. 2011. Effect of potassium humate on nutrients uptake of glycine max, phaseolus mungo and triticum aestivum. Plant Sci Feed.1: 174-178.

Piper CS. 1951. Soil and Plant Analysis. Inter-science Publishers. Inc. New York.

Poustini K, Siosemardeh A, Ranjbar M. 2007. Proline accumulation as a response to salt stress in 30 wheat (Triticum aestivum L.) cultivars differing in salt tolerance. Genet Resour Crop Evil. 54: 925-934.

Saqib M, Javaid A, Qureshi RH. 2004. Pot study on wheat growth in saline and waterlogged compacted soil II. Root growth and leaf ionic relations. Soil Tillage Res. 77: 179-187.

Sarwar M, Akhtar ME, Hyder SI, Khan MZ. 2012. Effect of bio stimulant (humic acid) on yield, phosphorus, potassium and boron use efficiency in peas. Persian Gulf Crop Protection. 1: 11-16.

Sharif M, Khattak RA, Sarir MS. 2002. Effect of different levels of lignitic coal derived humic acid on growth of maize plants. Commun Soil Sci Plant Anal. 33: $3567-3580$.

Shuixiu H, Ruizhen W. 2001. A study on the effect of KOMIX, humic acid containing organic fertilizer on spring soybean. Acta Agric. 23(4):463-466.

Siddhuraju P, Becker K. 2003. Antioxidant properties of various solvent extracts of total phenolic constituents from three different agro climatic origins of 
drumstick tree (Moringa oleifera Lam.) leaves. J Agric Food Chem. 51:2144 2155.

Tejera N, Ortega E, Rodes R, Lluch C. 2006. Nitrogen compounds in the apoplastic sap of sugarcane stem: Some implications in the association with endophytes. J Plant Physiol. 163:80-85.

Türkmen O, Dursun A, Turan M, Erdinc C. 2004. Calcium and humic acid affect seed germination, growth and nutrient content of tomato (Lycopersicon esculentum L.) seedlings under saline soil conditions. Acta Horticul Scandinavica B. 54: 168-174.

Thanaa ShM, Kassim NE, Rayya A, Abdalla AM (2017) Influence of Foliar Application with Moringa (Moringa oleifera L.) Leaf Extract on Yield and Fruit Quality of Hollywood Plum Cultivar. J Hortic 4:193. doi: $10.4172 / 2376-0354.1000193$

Vuelvas-Solozano ARH, Barajas EC, Guido MLL, Dendooven L, Manriquez MC. 2009. Dynamics of $\mathrm{C}^{14}$-labeled glucose and ammonium in saline arable soils. Revista Brasileira De Ciência Do Solo. 33: 857-865.

Wang XJ, Wang ZQ, Li SG. 1995. The effect of humic acids on the availability of phosphorus fertilizers in alkaline soils. Soil Use Manage.11: 99-102.

Watanabe FS, Olsen SR. 1965. Test of ascorbic acid method for determing phosphorus in water and $\mathrm{NaHCO}_{3}$ extracts from soil. Soil Sci. Soc. Am. Proc.29 : $677-$ 678. 
Table1. Some physical and chemical properties of the soils under study

\begin{tabular}{|c|c|c|c|c|c|c|c|c|c|c|c|}
\hline \multirow{3}{*}{ Soil } & \multirow{3}{*}{ Sand } & \multirow{3}{*}{$\begin{array}{l}\text { Silt } \\
--\%\end{array}$} & \multirow{3}{*}{ Clay } & \multirow{3}{*}{ Texture } & \multirow{3}{*}{$\mathrm{pH}^{\mathrm{a}}$} & \multirow[t]{2}{*}{$\mathrm{EC}^{\mathrm{b}}$} & \multirow{2}{*}{$\mathrm{CaCO}_{3}$} & \multirow{2}{*}{$\mathrm{OM}^{\mathrm{c}}$} & \multicolumn{3}{|c|}{ Available nutrients } \\
\hline & & & & & & & & & \multirow[t]{2}{*}{$\mathrm{N}$} & \multirow{2}{*}{$\begin{array}{c}\mathrm{P} \\
\mathrm{mg} \mathrm{kg}^{-1}\end{array}$} & \multirow[t]{2}{*}{$\mathrm{K}$} \\
\hline & & & & & & $\mathrm{dSm}^{-1}$ & ------g k & '------- & & & \\
\hline S1 & 42 & 37 & 21 & Loam & 7.89 & 3.01 & 55.32 & 6.42 & 60.42 & 8.95 & 92.14 \\
\hline $\mathrm{S} 2$ & 47 & 30 & 23 & Loam & 7.83 & 6.12 & 61.35 & 7.41 & 5845 & 8.12 & 91.02 \\
\hline S5 & 43 & 29 & 28 & Loam & 8.02 & 12.33 & 62.71 & 8.63 & 49.50 & 5.74 & 87.21 \\
\hline
\end{tabular}


Table 2.Chemical composition of Moringa oleifera leaves per dry weight (dw).

\begin{tabular}{|c|c|}
\hline Component & Value \\
\hline Protein & $273 \mathrm{~g} \mathrm{~kg}^{-1} \mathrm{dw}$ \\
\hline Phosphorus (P) & $3.90, \quad$, \\
\hline Potassium (K) & 21.70, \\
\hline Calcium (Ca) & 24.0, \\
\hline Magnesium (Mg) & $4.5,, \quad$, \\
\hline Iron $(\mathrm{Fe})$ & 0.582 \\
\hline Vitamin A ( $\beta$-carotene $)$ & $163 \mathrm{mgkg}^{-1}$ \\
\hline Vitamin B1(thiamine) & 26 \\
\hline Vitamin B2 (riboflavin) & 210 \\
\hline Vitamin B3(nicotinic acid) & 800 \\
\hline Vitamin C (ascorbic acid) & 1700 \\
\hline Vitamin E (tochopherol acetate) & $1130 \quad$, \\
\hline
\end{tabular}


Table 3. Effect of humic substances and foliar spray of Moringa leaf extract on fresh and dry weight of Sudan grass plants grown under salinity stress.

\begin{tabular}{|c|c|c|c|c|c|c|c|c|c|c|}
\hline \multirow{2}{*}{\multicolumn{3}{|c|}{ Factor of study ${ }^{\dagger}$}} & \multicolumn{3}{|c|}{$\begin{array}{l}\text { Fresh weight } \\
\left(\mathrm{g} \mathrm{pot}^{-1}\right)\end{array}$} & \multirow[b]{2}{*}{$\begin{array}{l}\text { Cumulative } \\
\text { fresh weight } \\
\qquad\left(\mathrm{g} \mathrm{pot}^{-1}\right)\end{array}$} & \multicolumn{3}{|c|}{$\begin{array}{c}\text { Dry weight } \\
\left(\mathrm{g} \mathrm{pot}^{-1}\right)\end{array}$} & \multirow[b]{2}{*}{$\begin{array}{l}\text { Cumulative } \\
\text { dry weight } \\
\left(\mathrm{g} \mathrm{pot}^{-1}\right)\end{array}$} \\
\hline & & & $1^{\text {st }}$ & $2^{\text {nd }}$ & $3^{\text {rd }}$ & & $1^{\text {st }}$ & $2^{\text {nd }}$ & $3^{\text {rd }}$ & \\
\hline \multicolumn{11}{|c|}{ Effect of soil salinity (A) } \\
\hline \multicolumn{3}{|c|}{$\mathrm{S} 1,\left(3.01 \mathrm{dSm}^{-1}\right)$} & $600 a$ & $576 a$ & $427 a$ & $1603 a$ & $100 a$ & $95.92 a$ & $71.15 a$ & $267 a$ \\
\hline \multicolumn{3}{|c|}{$\mathrm{S} 2,\left(6.12 \mathrm{dSm}^{-1}\right)$} & $568 b$ & $531 b$ & $367 b$ & $1465 b$ & $94.58 b$ & $88.54 b$ & $51.23 b$ & $234 b$ \\
\hline \multicolumn{3}{|c|}{$\mathrm{S} 3,\left(12.33 \mathrm{dSm}^{-1}\right)$} & $534 c$ & $489 c$ & $182 c$ & $1205 c$ & $89.03 c$ & $81.58 c$ & $30.36 c$ & $201 c$ \\
\hline \multicolumn{11}{|c|}{ Effect of humic substance (B) } \\
\hline \multicolumn{3}{|c|}{ Untreated } & $559 d$ & $518 d$ & $253 d$ & $1331 d$ & $93.21 d$ & $86.40 d$ & $42.19 d$ & $222 d$ \\
\hline \multicolumn{3}{|c|}{ HA } & $570 b$ & $535 b$ & $349 b$ & $1455 b$ & $94.92 b$ & $89.24 b$ & $58.14 b$ & $242 b$ \\
\hline \multicolumn{3}{|c|}{ FA } & $563 c$ & $528 c$ & $340 c$ & $1433 c$ & $93.84 c$ & $88.10 c$ & $56.59 c$ & $239 c$ \\
\hline \multicolumn{3}{|c|}{$\mathrm{HA}+\mathrm{FA}$} & $578 a$ & $546 a$ & $360 a$ & $1483 a$ & $96.26 a$ & $91.0 a$ & $60.05 a$ & $248 a$ \\
\hline \multicolumn{11}{|c|}{ Effect of moringa leaf extract (C) } \\
\hline \multicolumn{3}{|c|}{ Without } & $561 b$ & $525 b$ & $317 b$ & $1403 b$ & $93.45 b$ & $87.55 b$ & $52.90 b$ & $234 b$ \\
\hline \multicolumn{3}{|c|}{ With } & $573 a$ & $539 a$ & $333 a$ & $1445 a$ & $95.66 a$ & $89.82 a$ & $55.59 a$ & $241 a$ \\
\hline \multicolumn{11}{|c|}{ Effect the interaction $(A * B * C)$} \\
\hline \multirow{8}{*}{ 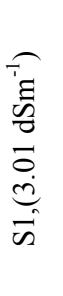 } & \multirow{2}{*}{ Untreated } & Without & $584 e f$ & $551 d$ & $401 g$ & $1536 g$ & $97.32 e f$ & $91.89 d$ & $66.86 \mathrm{~g}$ & $256 g$ \\
\hline & & With & $603 c$ & $572 c$ & $422 e$ & $1597 d$ & $100 c$ & $95.38 c$ & $70.28 e$ & $266 e$ \\
\hline & & Without & $595 d$ & $570 c$ & $426 d e$ & $1593 d e$ & $99.18 d$ & $95.32 c$ & $71.03 \mathrm{de}$ & $265 d e$ \\
\hline & HA & With & $610 a$ & $581 b$ & $439 b$ & $1630 b$ & $101 b$ & $96.87 b$ & $73.21 b$ & $272 b$ \\
\hline & & Without & $585 \mathrm{~d} e$ & $566 c$ & $415 f$ & $1566 f$ & $97.57 \mathrm{de}$ & $94.39 c$ & $69.23 f$ & $261 f$ \\
\hline & FA & With & $607 \mathrm{~b} c$ & $580 b$ & $429 c d$ & $1616 c$ & $101 b c$ & $96.72 b$ & $71.45 c d$ & $269 c d$ \\
\hline & & Without & $601 c$ & $582 b$ & $433 c$ & $1616 c$ & $100 c$ & $97.08 b$ & $72.11 c$ & $269 c$ \\
\hline & $\mathrm{HA}$ & With & $614 a$ & $599 a$ & $450 a$ & $1663 a$ & $103 a$ & $99.77 a$ & $75.05 a$ & $277 a$ \\
\hline & & Without & $552 \mathrm{kl}$ & $510 i$ & $335 m$ & $1397 m$ & $91.98 \mathrm{kl}$ & $85.02 i$ & $55.78 m$ & $233 m$ \\
\hline & Untreated & With & $563 i j$ & $516 h$ & $361 k$ & $1440 \mathrm{~lm}$ & $93.87 i j$ & $85.99 h$ & $60.25 k$ & $240 k$ \\
\hline छ & & Without & $565 i j$ & $533 f$ & $362 k$ & $1460 k$ & $94.22 i j$ & $88.77 f$ & $60.25 k$ & $243 k$ \\
\hline$\frac{2}{2}$ & HA & With & $578 f g$ & $543 e$ & $383 h$ & $1504 h$ & $96.32 f g$ & $90.52 e$ & $63.82 h$ & $251 h$ \\
\hline$\stackrel{\simeq}{!}$ & & Without & $564 j k$ & $527 g$ & $353 l$ & $1445 l$ & $94.14 j k$ & $87.75 g$ & $58.82 l$ & $241 l$ \\
\hline$\dot{0}$ & FA & With & $568 h i$ & $530 f g$ & $370 j$ & $1468 i$ & $94.69 h i$ & $88.31 f g$ & $61.69 j$ & $245 j$ \\
\hline$\tilde{N}$ & & Without & $574 g h$ & $542 e$ & $377 i$ & $1493 i$ & $95.60 \mathrm{gh}$ & $90.31 e$ & $62.80 i$ & $248 i$ \\
\hline & $\mathrm{HA}+\mathrm{FA}$ & With & $582 e f$ & $550 d$ & $399 g$ & $1531 g$ & 96.95ef & $91.73 d$ & $66.43 g$ & $255 a$ \\
\hline & Untreated & Without & $522 q$ & $470 m$ & $000 r$ & $992 r$ & $87.07 q$ & $78.40 m$ & $0.00 r$ & $165 r$ \\
\hline$\approx$ & Untreated & With & $528 o p$ & $490 k$ & $000 r$ & $1018 r$ & $88.05 o p$ & $81.73 k$ & $0.00 r$ & $169 r$ \\
\hline$\stackrel{\Xi}{0}$ & & Without & 531op & $482 l$ & $234 q$ & $1247 q$ & $88.52 o p$ & $80.37 l$ & $38.9 q$ & $207 q$ \\
\hline$m$ & HA & With & $542 m$ & $502 j$ & $250 o$ & $1294 o$ & $90.25 \mathrm{~m}$ & $83.65 j$ & $41.62 o$ & $215 o$ \\
\hline$\stackrel{n}{i}$ & & Without & $526 p q$ & $474 m$ & $229 q$ & $1229 q$ & $87.59 p q$ & $79.02 m$ & $38.19 q$ & $205 q$ \\
\hline-2 & FA & With & 534 no & $494 k$ & $241 p$ & $1269 p$ & 89.04no & $82.41 k$ & $40.18 p$ & $211 p$ \\
\hline$\hat{n}$ & & Without & $537 m n$ & $493 k$ & $245 o p$ & $1276 o p$ & $89.53 m n$ & $82.30 k$ & 40.76op & $213 o p$ \\
\hline & $\mathrm{H}$ & With & $549 n$ & $509 i$ & $259 n$ & $1317 n$ & $91.52 l$ & $84.77 i$ & $43.16 n$ & $219 n$ \\
\hline Effe & ct of the inte & $\operatorname{action}(\mathrm{B}$ & & & & & & & & \\
\hline & & Without & $553 e$ & $511 f$ & $245 h$ & $1309 h$ & $92.12 e$ & $85.10 f$ & $40.88 h$ & $218 h$ \\
\hline & ntreated & With & $565 d$ & $526 d$ & $261 g$ & $1352 g$ & $94.15 d$ & $87.70 d$ & $43.51 \mathrm{~g}$ & $225 g$ \\
\hline & $\mathrm{HA}$ & Without & $564 d$ & $529 d$ & $340 e$ & $1433 e$ & $93.97 d$ & $88.15 d$ & $56.75 e$ & $238 e$ \\
\hline & HA & With & $577 b$ & $542 b$ & $357 b$ & $1476 b$ & $96.09 b$ & $90.35 b$ & $59.55 b$ & $246 b$ \\
\hline & & Without & $559 e$ & $522 e$ & $332 f$ & $1413 f$ & $93.10 e$ & $87.06 e$ & $55.42 f$ & $235 f$ \\
\hline & FA & With & $570 c$ & $535 c$ & $347 d$ & $1452 d$ & $94.95 c$ & $89.15 c$ & $57.78 d$ & $242 d$ \\
\hline & & Without & $571 c$ & $539 b$ & $351 c$ & $1461 c$ & $95.12 c$ & $89.90 b$ & $58.56 c$ & $244 c$ \\
\hline & $\mathrm{HA}+\mathrm{FA}$ & With & $582 a$ & $553 a$ & $369 a$ & $1504 a$ & $96.96 a$ & $92.09 a$ & $61.55 a$ & $251 a$ \\
\hline
\end{tabular}

Note: Mean values in the same column for each trait followed by the same a lower case italic letter are not significantly different according to Duncan's multiple range test at $P \leq 0.05$.

$\uparrow$ Factor of study: $A=$ Salinity effects, $B=$ Humic substances effects, $C=$ Moringa leaf extract effects. $\mathrm{HA}=$ Humic Acid, FA $=$ Falvic Acid, $1^{\text {st }}=$ First cut, $2^{\text {nd }}=$ Second cut and $3^{\text {rd }}=$ Third cut 
Table 4. Effect of humic substances and foliar spray of Moringa leaf extract on plant height, total chlorophyll and proline of Sudan grass plants grown under salinity stress.

\begin{tabular}{|c|c|c|c|c|c|c|c|c|c|c|c|}
\hline \multirow{2}{*}{\multicolumn{3}{|c|}{ Factor of study ${ }^{\dagger}$}} & \multicolumn{3}{|c|}{ Plant height $(\mathrm{cm})$} & \multicolumn{3}{|c|}{ Total chlorophyll ( $\left.\mathrm{mg} \mathrm{g}^{-1} \mathrm{fwt}\right)$} & \multicolumn{3}{|c|}{ Proline $\left(\mathrm{mg} \mathrm{g}^{-1} \mathrm{~d} \mathrm{wt}\right)$} \\
\hline & & & $1^{\mathrm{st}}$ & $2^{\text {nd }}$ & $3^{\text {rd }}$ & $1^{\mathrm{st}}$ & $2^{\text {nd }}$ & $3^{\text {rd }}$ & $1^{\mathrm{st}}$ & $2^{\text {nd }}$ & $3^{\text {rd }}$ \\
\hline \multicolumn{12}{|c|}{ Effect of soil salinity (A) } \\
\hline \multicolumn{3}{|c|}{$\mathrm{S} 1,\left(3.01 \mathrm{dSm}^{-1}\right)$} & $158 a$ & $144 a$ & $79.67 a$ & $1.84 a$ & $1.58 a$ & $1.17 a$ & $17.67 c$ & $14.06 c$ & $11.18 c$ \\
\hline \multicolumn{3}{|c|}{$\mathrm{S} 2,\left(6.12 \mathrm{dSm}^{-1}\right)$} & $126 b$ & $102 b$ & $56.34 b$ & $1.57 b$ & $1.37 b$ & $0.95 b$ & $19.41 b$ & $15.70 b$ & $12.03 b$ \\
\hline \multicolumn{3}{|c|}{$\mathrm{S} 3,\left(12.33 \mathrm{dSm}^{-1}\right)$} & $86.56 c$ & $60.8 c$ & $26.67 c$ & $1.44 c$ & $1.12 c$ & $0.61 c$ & $24.42 a$ & $19.3 a$ & $12.67 a$ \\
\hline \multicolumn{12}{|c|}{ Effect of humic substance (B) } \\
\hline \multicolumn{3}{|c|}{ Untreated } & $108 d$ & $89.64 d$ & $40.77 d$ & $1.53 d$ & $1.26 d$ & $0.64 d$ & $19.07 d$ & $14.07 d$ & $6.64 d$ \\
\hline \multicolumn{3}{|c|}{ HA } & $127 b$ & $106 b$ & $58.07 b$ & $1.64 b$ & $1.39 b$ & $1.00 b$ & $21.08 b$ & $17.01 b$ & $13.99 b c$ \\
\hline \multicolumn{3}{|c|}{ FA } & $123 c$ & $101 c$ & $55.02 c$ & $1.56 c$ & $1.31 c$ & $0.94 c$ & $20.11 c$ & $16.14 c$ & $12.79 c$ \\
\hline & $\mathrm{HA}+\mathrm{F}$ & & $134 a$ & $112 a$ & $63.03 a$ & $1.73 a$ & $1.48 a$ & $1.06 a$ & $21.74 a$ & $17.58 a$ & $14.43 a$ \\
\hline \multicolumn{12}{|c|}{ Effect of moringa leaf extract (C) } \\
\hline \multicolumn{3}{|c|}{ Without } & $117 b$ & $94.0 b$ & $49.24 b$ & $1.50 b$ & $1.29 b$ & $0.87 b$ & $19.99 b$ & $15.16 b$ & $11.28 b$ \\
\hline \multicolumn{3}{|c|}{ With } & $130 a$ & $111 a$ & $59.22 a$ & $1.73 a$ & $1.42 a$ & $0.95 a$ & $21.02 a$ & $17.56 a$ & $12.64 a$ \\
\hline \multicolumn{12}{|c|}{ Effect the interaction $\left(\mathrm{A}^{*} \mathrm{~B} * \mathrm{C}\right)$} \\
\hline \multirow{8}{*}{ 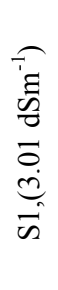 } & \multirow{2}{*}{ Untreated } & Without & $141 d$ & $124 g$ & $68.36 g$ & $1.65 \mathrm{cdefg}$ & $1.42 b c d e f$ & $1.02 a b c d e f g$ & $16.18 l$ & $11.1 j$ & $8.19 i$ \\
\hline & & With & $150 c$ & $133 f$ & $81.32 d$ & $1.79 b c d$ & $1.55 \mathrm{abcd}$ & $1.10 a b c d e f$ & $16.82 \mathrm{kl}$ & 13.12hij & $10.03 g h$ \\
\hline & \multirow{2}{*}{ HA } & Without & $153 c$ & $141 d$ & $73.11 f$ & $1.84 b c d$ & $1.59 a b c d$ & $1.23 a b c$ & 18.52ghijk & $13.51 h i$ & $11.31 \mathrm{efgh}$ \\
\hline & & With & $169 a$ & $155 b$ & $86.71 b$ & $1.96 a b$ & $1.66 a b c$ & $1.21 \mathrm{abcd}$ & $17.63 j k l$ & $16.13 \mathrm{efg}$ & $12.88 \mathrm{de}$ \\
\hline & & Without & $152 c$ & $137 e$ & $70.80 f$ & $1.71 b c d e f$ & $1.43 b c d e f$ & $1.09 a b c d e f$ & $17.66 i j k l$ & $13.02 i j$ & $9.86 h$ \\
\hline & FA & With & $168 a$ & $150 c$ & $84.23 c$ & $1.87 b c$ & $1.57 a b c d$ & $1.14 a b c d e$ & $17.02 j k l$ & $14.69 g h i$ & $11.61 e f g$ \\
\hline & & Without & $160 b$ & $148 c$ & $79.21 e$ & $1.86 b c$ & $1.67 a b$ & $1.29 a b$ & 18.28ghijk & $13.98 h i$ & $11.98 e f$ \\
\hline & $\mathrm{HA}+\mathrm{FA}$ & With & $170 a$ & $161 a$ & $92.63 a$ & $1.99 a$ & $1.80 a$ & $1.32 a$ & 18.61ghijk & $16.91 e f$ & $13.63 c d$ \\
\hline & Untreated & Without & $103 i$ & $86.41 k$ & $43.62 l$ & $1.35 i j k$ & $1.24 d f f g h$ & $0.83 e f g$ & $16.83 \mathrm{kl}$ & $13.63 h i$ & $10.13 g h$ \\
\hline & Untreated & With & $110 h$ & $99.6 j$ & $51.36 j$ & $1.64 c d e f g h$ & $1.33 b c d e f g h$ & $0.93 c d e f g$ & 18.19hijk & $14.68 g h i$ & $11.51 \mathrm{efg}$ \\
\hline ڤี & $\mathrm{HA}$ & Without & $124 g$ & $92.42 k$ & $50.26 \mathrm{j}$ & 1.52efghij & $1.30 b c d e f g h$ & $0.94 c$ defg & $19.67 f g h$ & $15.26 f g h$ & $12.63 \mathrm{def}$ \\
\hline 0 & HA & With & $136 e$ & $116 h$ & $66.31 h$ & $1.73 b c d e f$ & $1.48 a b c d e f$ & $1.03 a b c d e f g$ & $20.98 e f$ & 17.11 ef & $12.91 \mathrm{de}$ \\
\hline$\underset{1}{1}$ & & Without & $127 g$ & $89.80 k$ & $47.82 k$ & 1.51efghijk & $1.29 c d e f g h$ & $0.86 e f g$ & $19.71 \mathrm{fgh}$ & 14.98fghi & $11.19 \mathrm{fgh}$ \\
\hline 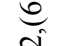 & FA & With & $130 f$ & $109 i$ & $58.26 i$ & $1.69 c d e f$ & $1.41 b c d e f$ & $1.02 a b c d e f g$ & $19.62 f g h i$ & $16.16 \mathrm{efg}$ & 11.96ef \\
\hline బ & $\mathrm{HA}+\mathrm{FA}$ & Without & $129 f$ & $101 j$ & $59.31 i$ & 1.60defgh & $1.40 b c d e f$ & $0.96 b c d e f g$ & $20.18 \mathrm{efg}$ & $16.15 \mathrm{efg}$ & $12.85 \mathrm{de}$ \\
\hline & НА + ГА & With & $160 b$ & $123 g$ & $71.82 f$ & $1.76 b c d e$ & $1.54 a b c d e$ & $1.07 a b c d e f$ & $21.63 \mathrm{de}$ & $17.68 \mathrm{de}$ & $12.98 \mathrm{de}$ \\
\hline & & Without & $69.11 \mathrm{~m}$ & $43.7 r$ & $0.00 r$ & $1.27 k$ & $1.00 h$ & $0.00 h$ & $21.87 d e$ & $16.27 e f g$ & $0.00 j$ \\
\hline$\overparen{\tau}$ & Untreated & With & $75.24 l$ & $51.3 q$ & $0.000 r$ & $1.33 i j k$ & $1.02 g$ & $0.00 h$ & $23.10 c d$ & $19.36 c d$ & $0.00 j$ \\
\hline की & $\mathrm{HA}$ & Without & $83.61 k$ & $55.3 p$ & $31.82 p q$ & 1.39ghijk & $1.11 \mathrm{gh}$ & $0.78 f g$ & $23.74 b c$ & $18.07 \mathrm{de}$ & $16.11 b$ \\
\hline$m$ & $\mathrm{HA}$ & With & $98.39 i$ & $76.2 m$ & $39.268 n$ & 1.55defghi & $1.22 \mathrm{defgh}$ & 0.87 defg & $25.96 a$ & $21.98 a b$ & $18.10 a$ \\
\hline ก่ & FA & Without & $80.36 k l$ & $49.7 q$ & $30.91 q$ & $1.29 j k$ & $1.026 \mathrm{gh}$ & $0.72 g$ & $23.17 c d$ & $17.69 \mathrm{de}$ & $14.61 c$ \\
\hline$=$ & FA & With & $93.26 j$ & $71.4 n$ & $36.11 o$ & 1.51efghijk & $1.18 \mathrm{efgh}$ & $0.82 e f g$ & $24.99 a b c$ & $20.36 b c$ & $17.55 a b$ \\
\hline$\hat{n}$ & & Without & $92.47 j$ & $60.4 o$ & $33.69 p$ & 1.53efghij & $1.16 f g h$ & $0.83 \mathrm{efg}$ & $25.68 a b$ & $18.18 \mathrm{de}$ & $16.38 b$ \\
\hline & HA + FA & With & $99.8 i$ & $79.2 m$ & $41.63 m$ & 1.61defgh & $1.30 b c d e f g h$ & 0.90 cdefg & $25.88 a$ & $22.61 a$ & $18.63 a$ \\
\hline Effe & ct of the inte & raction (B & & & & & & & & & \\
\hline & Intro & Without & $104 h$ & $84.57 g$ & $37.33 h$ & $1.42 d$ & $1.22 c$ & $0.62 c$ & $18.30 d$ & $13.69 d$ & $6.11 f$ \\
\hline & Jntreated & With & $112 g$ & $94.72 e$ & $44.23 g$ & $1.59 b c$ & $1.30 b c$ & $0.68 c$ & $19.37 c$ & $15.72 c$ & $7.18 g$ \\
\hline & HA & Without & $120 e$ & $96.33 e$ & $52.06 e$ & $1.59 b c$ & $1.33 b c$ & $0.98 a b$ & $20.65 b c$ & $15.61 c$ & $13.35 d$ \\
\hline & HA & With & $134 b$ & $116 b$ & $64.09 b$ & $1.74 a b$ & $1.45 a b$ & $1.04 a b$ & $21.52 a b$ & $18.41 a$ & $14.63 b$ \\
\hline & FA & Without & $119 f$ & $92.1 f$ & $50.18 e$ & $1.51 c d$ & $1.23 c$ & $0.89 b$ & $20.19 c$ & $15.23 c$ & $11.89 e$ \\
\hline & FA & With & $130 c$ & $110 c$ & $59.87 c$ & $1.69 b$ & $1.38 a b c$ & $0.99 a b$ & $20.54 b c$ & $17.07 b$ & $13.71 c$ \\
\hline & $\mathrm{HA}+\mathrm{F}$ & Without & $127 d$ & $103 d$ & $57.40 d$ & $1.67 b c$ & $1.41 a b c$ & $1.02 a b$ & $21.50 a b$ & $16.1 b c$ & $13.78 c$ \\
\hline & $\mathrm{HA}+\mathrm{FA}$ & With & $142 a$ & $121 a$ & $68.69 a$ & $1.79 a$ & $1.55 a$ & $1.10 a$ & $21.93 a$ & $19.07 a$ & $15.08 a$ \\
\hline
\end{tabular}

Note: Mean values in the same column for each trait followed by the same a lower case italic letter are not significantly different according to Duncan's multiple range test at $P \leq 0.05$.

$\uparrow$ Factor of study: $A=$ Salinity effects, $B=$ Humic substances effects, $C=$ Moringa leaf extract effects. $\mathrm{HA}=$ Humic Acid, FA $=$ Falvic Acid, $1^{\text {st }}=$ First cut, $2^{\text {nd }}=$ Second cut and $3^{\text {rd }}=$ Third cut 
Table5. Effect of humic substances and foliar spray of Moringa leaf extract on N, P and K-uptake by Sudan grass plants grown under salinity stress

\begin{tabular}{|c|c|c|c|c|c|c|c|c|c|c|c|}
\hline \multirow{2}{*}{\multicolumn{3}{|c|}{ Factor of study $\dagger$}} & \multicolumn{3}{|c|}{ N-uptake $\left(\right.$ mg pot $\left.^{-1}\right)$} & \multicolumn{3}{|c|}{ P-uptake $\left(\mathrm{mg} \mathrm{pot}^{-1}\right)$} & \multicolumn{3}{|c|}{ K-uptake $\left(\mathrm{mg} \mathrm{pot}^{-1}\right)$} \\
\hline & & & $1^{\text {st }}$ & $2^{\text {nd }}$ & $3^{\text {rd }}$ & $1^{\text {st }}$ & $2^{\text {nd }}$ & $3^{\text {rd }}$ & $1^{\text {st }}$ & $2^{\text {nd }}$ & $3^{\text {rd }}$ \\
\hline \multicolumn{12}{|c|}{ Effect of soil salinity (A) } \\
\hline \multicolumn{3}{|c|}{$\mathrm{S} 1,\left(3.01 \mathrm{dSm}^{-1}\right)$} & $3200 a$ & $2958 a$ & $1942 a$ & $302 a$ & $281 a$ & $184 a$ & $1946 a$ & $1818 a$ & $1237 a$ \\
\hline \multicolumn{3}{|c|}{$\mathrm{S} 2,\left(6.12 \mathrm{dSm}^{-1}\right)$} & $2689 b$ & $2439 b$ & $1399 b$ & $204 b$ & $187 b$ & $122 b$ & $1525 b$ & $1399 b$ & $957 b$ \\
\hline \multicolumn{3}{|c|}{$\mathrm{S} 3,\left(12.33 \mathrm{dSm}^{-1}\right)$} & $1943 c$ & $1761 c$ & $543 c$ & $156 c$ & $140 c$ & $62.20 c$ & $1020 c$ & $905 c$ & $315 c$ \\
\hline \multicolumn{12}{|c|}{ Effect of humic substance (B) } \\
\hline \multicolumn{3}{|c|}{ Untreated } & $2120 d$ & $1899 d$ & $893 d$ & $154 d$ & $135 d$ & $63.88 d$ & $1162 d$ & $1048 d$ & $521 d$ \\
\hline \multicolumn{3}{|c|}{ HA } & $2398 c$ & $2195 c$ & $1266 c$ & $192 c$ & $176 c$ & $127 c$ & $1354 c$ & $1253 c$ & $763 c$ \\
\hline \multicolumn{3}{|c|}{ FA } & $2748 b$ & $2525 b$ & $1377 b$ & $235 b$ & $217 b$ & $129 b$ & $1537 b$ & $1428 b$ & $907 b$ \\
\hline \multicolumn{3}{|c|}{$\mathrm{HA}+\mathrm{FA}$} & $3177 a$ & $2925 a$ & $1643 a$ & $303 a$ & $283 a$ & $172 a$ & $1935 a$ & $1767 a$ & $1156 a$ \\
\hline \multicolumn{12}{|c|}{ Effect of moringa leaf extract $(\mathrm{C})$} \\
\hline \multicolumn{3}{|c|}{ Without } & $2500 b$ & $2293 b$ & $1229 b$ & $207 b$ & $189 b$ & $118 b$ & $1417 b$ & $1300 b$ & $778 b$ \\
\hline \multicolumn{3}{|c|}{ With } & $2721 a$ & $2480 a$ & $1360 a$ & $235 a$ & $216 a$ & $128 a$ & $1576 a$ & $1449 a$ & $896 a$ \\
\hline \multicolumn{12}{|c|}{ Effect the interaction $(\mathrm{A} * \mathrm{~B} * \mathrm{C})$} \\
\hline \multirow{8}{*}{ 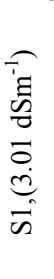 } & Untreate & Without & $2517 i$ & $2221 j k$ & $1549 h$ & $198 i$ & $168 i$ & $103 e f g h$ & $1518 g$ & $1369 j$ & $672 h i j$ \\
\hline & $\mathrm{d}$ & With & $2791 g$ & $2490 g h$ & $1708 \mathrm{~g}$ & $235 g$ & $213 g$ & 131 cdefg & $1675 f$ & $1545 \mathrm{hi}$ & $1040 e f$ \\
\hline & \multirow{2}{*}{ HA } & Without & $2816 g$ & $2621 f g$ & $1830 f$ & $245 f$ & $229 f$ & $156 b c d e f$ & $1686 f$ & $1611 g h$ & 1172 de \\
\hline & & With & $3139 e f$ & 2816ef & $1943 d$ & $271 e$ & $252 e$ & $185 b c d$ & $1814 e$ & $1708 e f$ & $1029 e f$ \\
\hline & & Without & $3181 e$ & 2961de & $1892 e$ & $290 d$ & $274 d$ & $187 b c d$ & $1822 e$ & $1743 e$ & $1269 c d$ \\
\hline & FA & With & $3485 c$ & $3283 c$ & $2024 c$ & $351 c$ & $329 c$ & $202 a b c$ & $2070 c$ & $1957 c$ & $1386 b c$ \\
\hline & $\mathrm{HA}+$ & Without & $3668 b$ & $3501 b$ & $2142 b$ & $394 b$ & $372 b$ & $233 a b$ & $2342 b$ & $2177 b$ & $1543 b$ \\
\hline & FA & With & $3864 a$ & $3775 a$ & $2449 a$ & $416 a$ & $409 a$ & $275 a$ & $2554 a$ & $2434 a$ & $1791 a$ \\
\hline & Untreate & Without & $2005 m$ & 1780 no & $997 m$ & 138 no & $119 k$ & $63.2 \mathrm{ghi}$ & $1092 j k$ & $972 m$ & $617 i j k$ \\
\hline$\frown$ & $\mathrm{d}$ & With & $2184 k$ & $1992 m$ & $1104 l$ & $153 m$ & $138 j$ & 86.4efgh & $1277 i$ & $1150 l$ & $799 g h i$ \\
\hline ' & & Without & $2340 j$ & $2181 j k l$ & $1205 k$ & $170 k$ & $157 i$ & $96.2 e f g h$ & $1395 h$ & $1269 k$ & $850 \mathrm{fgh}$ \\
\hline$\approx$ & HA & With & $2546 i$ & $2372 h i j$ & $1323 j$ & $186 j$ & $169 i$ & $115 \mathrm{defgh}$ & $1515 \mathrm{~g}$ & $1391 j$ & 966efg \\
\hline$\cong$ & & Without & $2638 h$ & $2474 g h i$ & $1392 i$ & $199 h i$ & $187 h$ & $124 c d e f g h$ & $1531 \mathrm{~g}$ & $1436 j$ & 951efg \\
\hline$\dot{0}$ & FA & With & $3084 f$ & $2762 e f$ & $1560 h$ & $227 g$ & $206 g$ & $140 \mathrm{cdefg}$ & $1645 f$ & $1522 i$ & $1045 e f$ \\
\hline สึ & $\mathrm{HA}+$ & Without & $3251 d$ & $2903 d e$ & $1692 g$ & $265 e$ & $247 e$ & $165 b c d e$ & $1778 e$ & $1665 f g$ & $1135 \mathrm{de}$ \\
\hline & FA & With & $3429 c$ & $3055 d$ & $1922 e$ & $294 d$ & $272 d$ & $186 b c d$ & $1952 d$ & $1789 d$ & $1295 c d$ \\
\hline & Untreate & Without & $1579 p$ & $1401 q$ & $0.00 s$ & $90.01 q$ & $76.2 m$ & $0.00 i$ & $679 n$ & $596 q$ & $000 r$ \\
\hline 'ב & $\mathrm{d}$ & With & $1620 o p$ & $1512 p q$ & $0.00 s$ & $103 p$ & $98.3 l$ & $0.00 i$ & $707 m n$ & $662 p q$ & $000 r$ \\
\hline$\overline{0}$ & & Without & $1709 \mathrm{o}$ & $1527 p q$ & $612 r$ & $147 m n$ & $134 j$ & 49.90hi & $800 m$ & $712 p$ & $256 m$ \\
\hline$m$ & HA & With & $1802 n$ & $1659 o p$ & $684 p q$ & $130 o$ & $115 k$ & $56.20 i$ & $921 l$ & $825 o$ & $311 \mathrm{~m}$ \\
\hline$\stackrel{m}{i}$ & & Without & $1954 m$ & 1751 no & $667 q$ & $161 \mathrm{kl}$ & $140 j$ & $55.9 h i$ & $1019 k$ & $895 n$ & $344 \mathrm{~lm}$ \\
\hline$=$ & FA & With & $2110 l$ & $1920 m n$ & $726 p$ & $184 j$ & $165 i$ & $65.58 g h i$ & $1122 j$ & $1014 m$ & $448 \mathrm{klm}$ \\
\hline$\hat{n}$ & $\mathrm{HA}+$ & Without & $2212 k$ & $2044 \mathrm{klm}$ & 7760 & $203 h$ & $187 h$ & 76.09fghi & $1265 \mathrm{hi}$ & $1148 l$ & $527 j k l$ \\
\hline & FA & With & $2477 i$ & $2278 \mathrm{ij}$ & $883 n$ & $232 g$ & $209 g$ & 93.50efgh & $1556 \mathrm{~g}$ & $1385 j$ & 642 hijk \\
\hline & ct of the in & eraction (B & & & & & & & & & \\
\hline & tred & Without & $2034 h$ & $1800 f$ & $849 g$ & $142 h$ & $121 h$ & $55.26 c$ & $1096 h$ & $979 h$ & $430 f$ \\
\hline & ntreated & With & $2199 g$ & $1998 e$ & $937 f$ & $164 g$ & $150 g$ & $72.52 c$ & $1220 \mathrm{~g}$ & $1119 g$ & $613 e$ \\
\hline & & Without & $2288 f$ & $2110 e$ & $1216 e$ & $181 f$ & $167 f$ & $136 b$ & $1294 f$ & $1198 f$ & $759 d$ \\
\hline & HA & With & $2496 e$ & $2282 d$ & $1316 d$ & $202 e$ & $185 e$ & $117 b$ & $1417 e$ & $1308 e$ & $768 d$ \\
\hline & & Without & $2591 d$ & $2395 d$ & $1317 d$ & $216 d$ & $200 d$ & $122 b$ & $1457 d$ & $1358 d$ & $855 c d$ \\
\hline & FA & With & $2893 c$ & $2655 c$ & $1437 c$ & $254 c$ & $233 c$ & $135 b$ & $1612 c$ & $1498 c$ & $960 b c$ \\
\hline & & Without & $3043 b$ & $2867 b$ & $1536 b$ & $287 b$ & $268 b$ & $158 a b$ & $1795 b$ & $1664 b$ & $1068 b$ \\
\hline & $\mathrm{A}+\mathrm{FA}$ & With & $3257 a$ & $2985 a$ & $1751 a$ & $314 a$ & $297 a$ & $185 a$ & $2021 a$ & $1869 a$ & $1243 a$ \\
\hline
\end{tabular}

Note: Mean values in the same column for each trait followed by the same a lower case italic letter are not significantly different according to Duncan's multiple range test at $P \leq 0.05$.

$\uparrow$ Factor of study: $A=$ Salinity effects, $B=$ Humic substances effects, $C=$ Moringa leaf extract effects. $\mathrm{HA}=$ Humic Acid, FA $=$ Falvic Acid, $1^{\text {st }}=$ First cut, $2^{\text {nd }}=$ Second cut and $3^{\text {rd }}=$ Third cut 


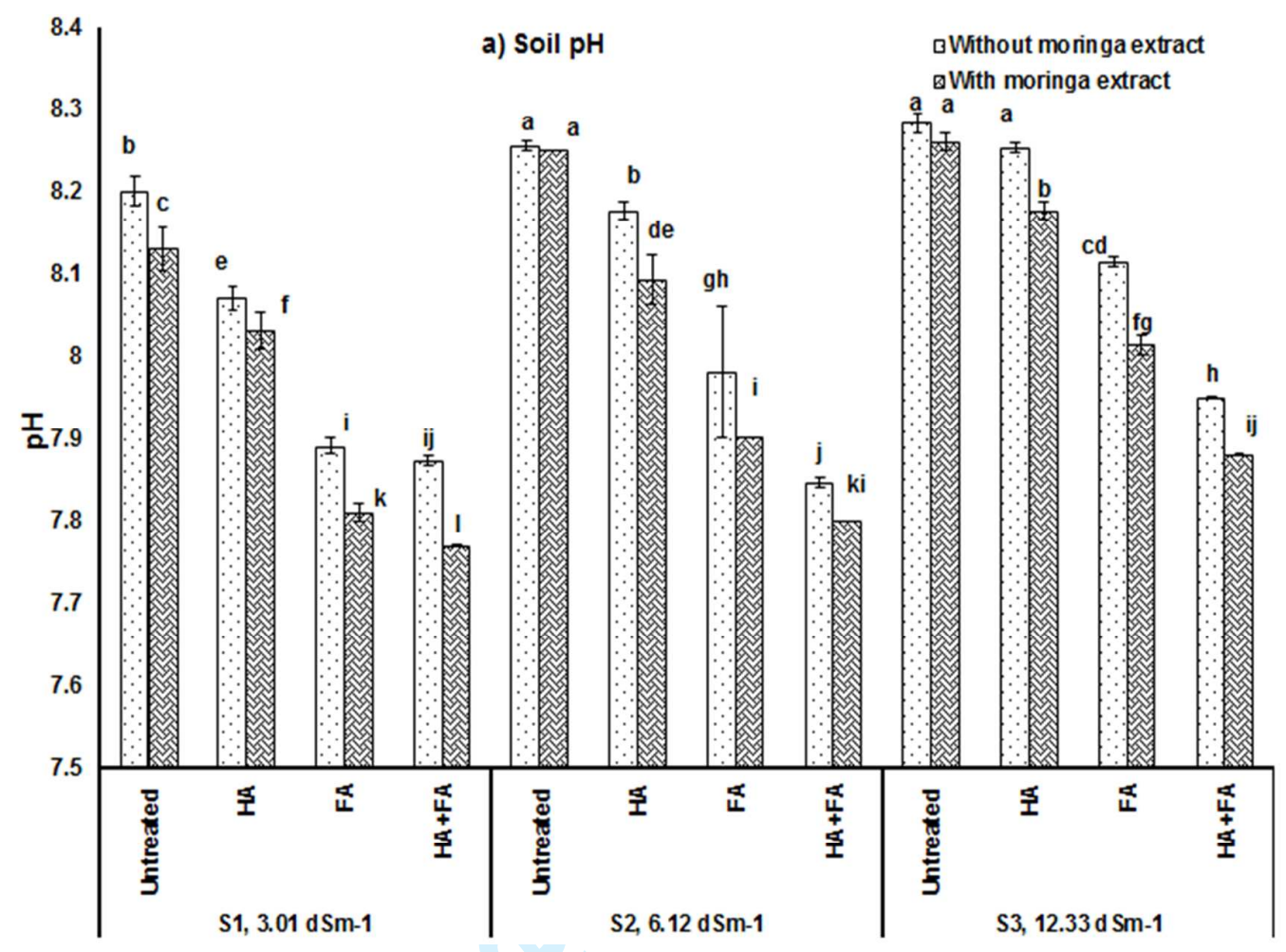

b) Available nitrogen

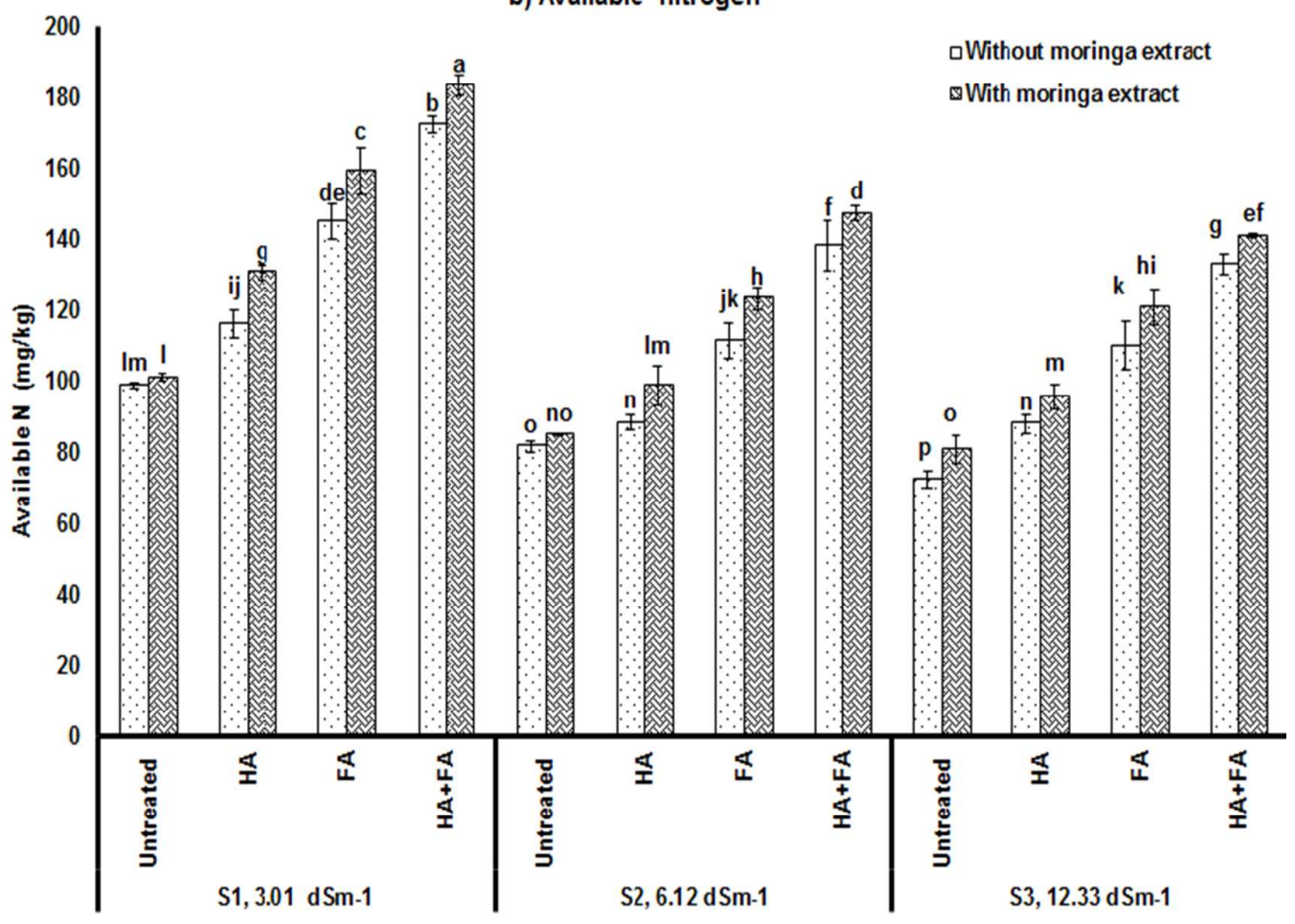

Figure 1. Effect of humic substances and foliar spray of Moringa leaf extract on a) soil $\mathrm{pH}$ and b) available nitrogen under salinity stress. Error bars represent standard deviation. 


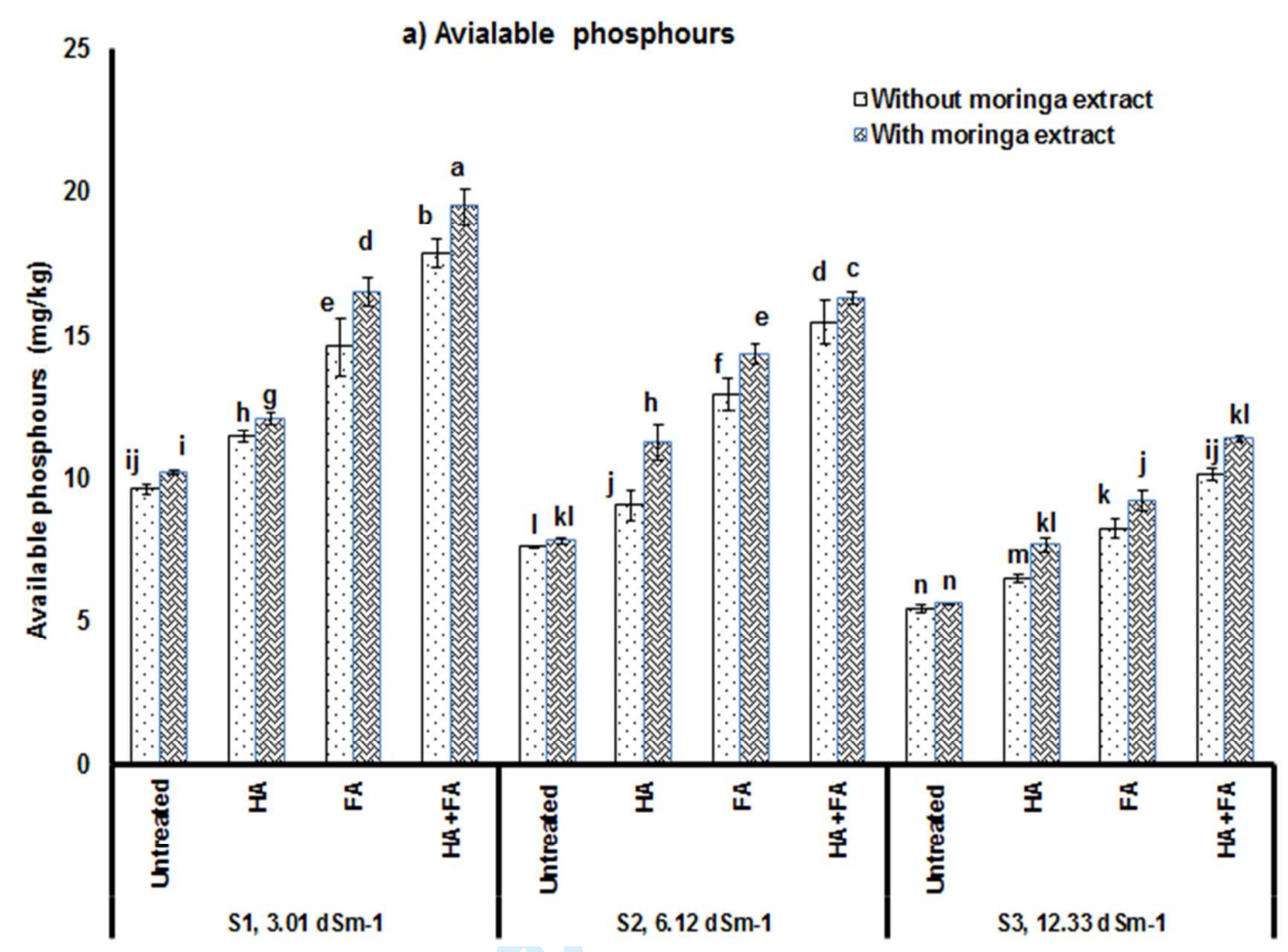

b) Available potassium

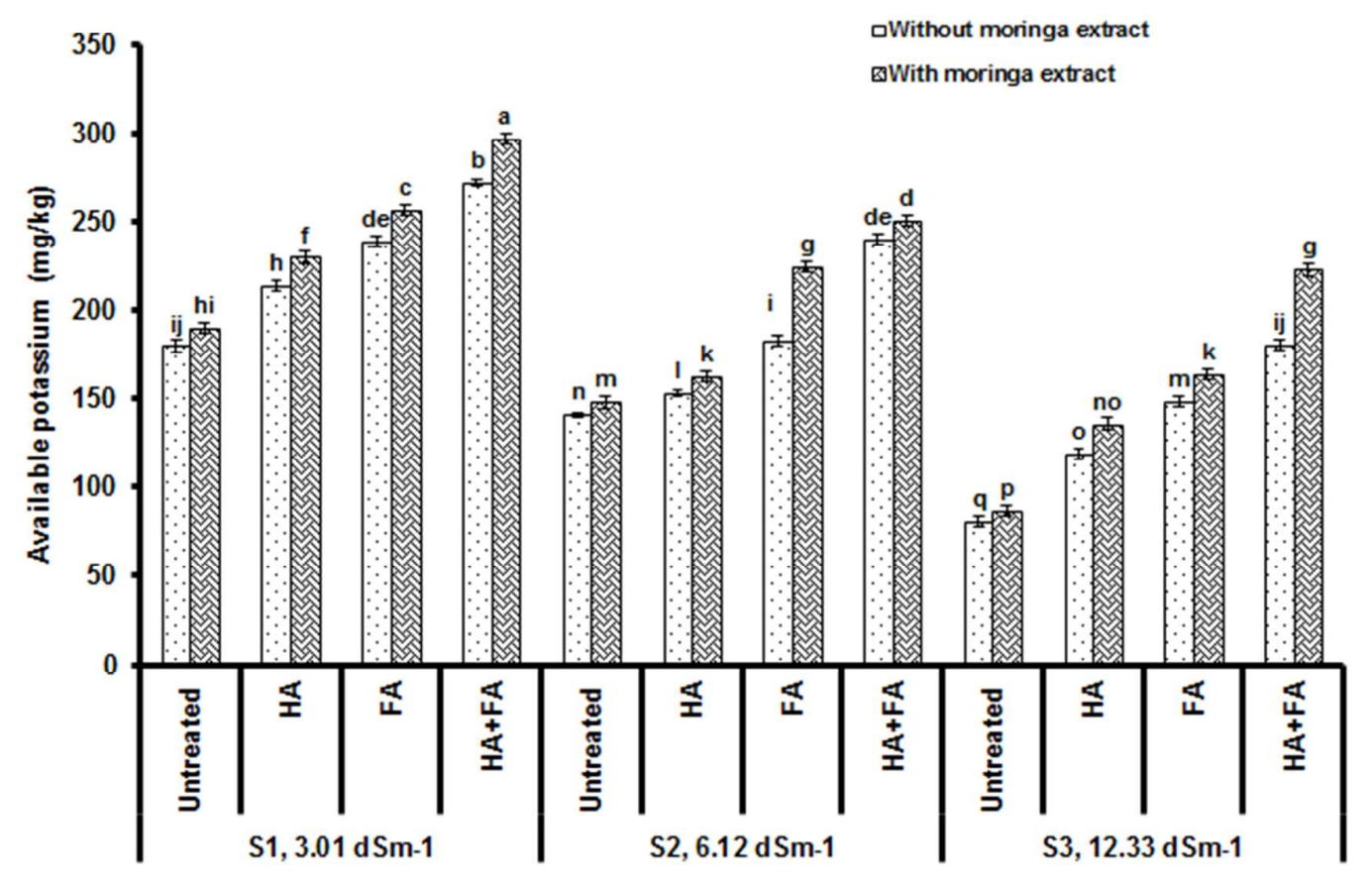

Figure 2. Effect of humic substances and foliar spray of Moringa leaf extract on a) available phosphorus and b) potassium under salinity stress. Error bars represent standard deviation. 


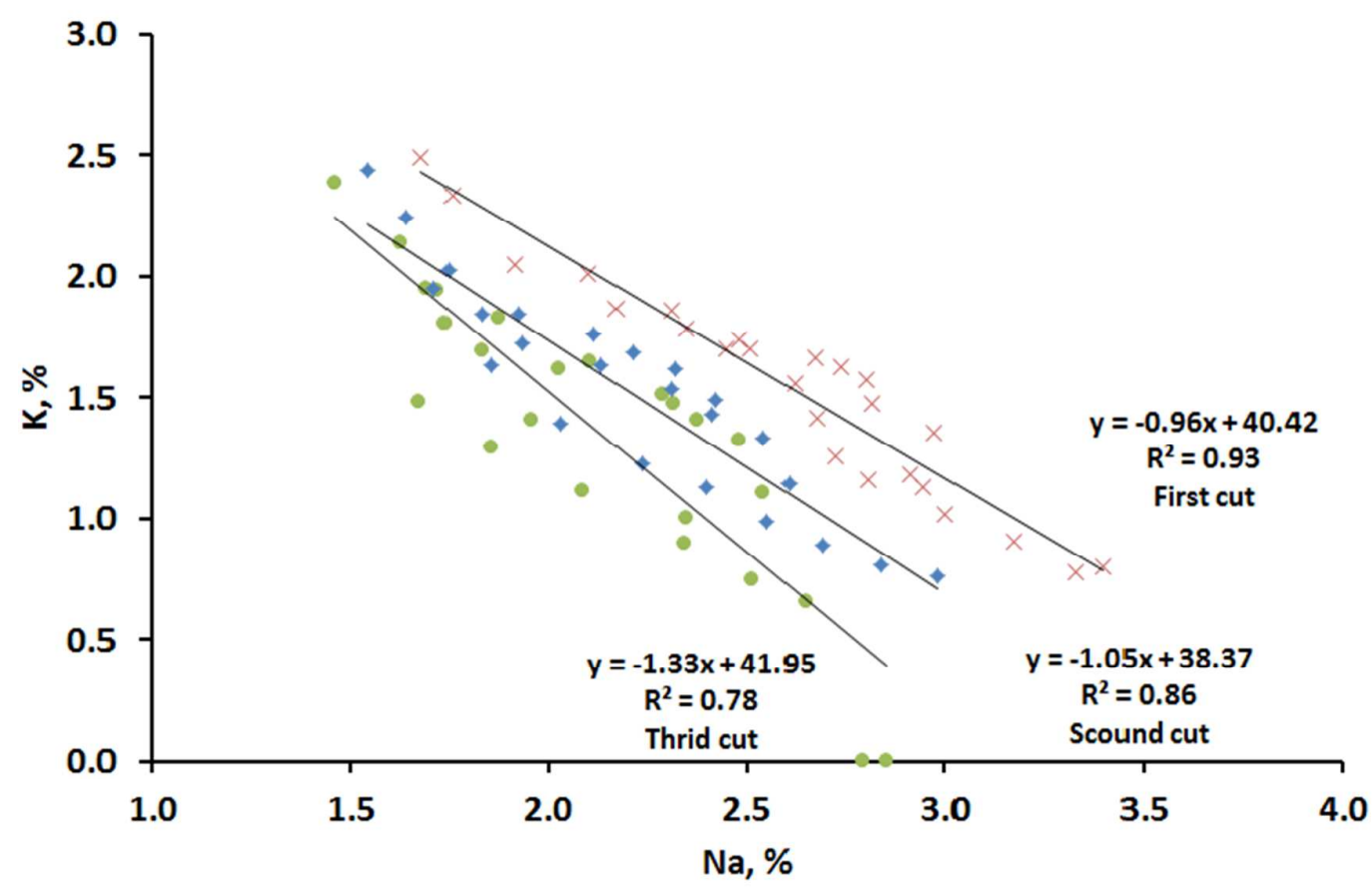

Figure 3. Relationship between $\mathrm{K}$ and $\mathrm{Na}$ concentration at different cuts as affected by soil salinity and humic substances and Moringa leaf extract. 